Article

\title{
Trends in Playa Inundation and Water Storage in the Ogallala Aquifer on the Texas High Plains
}

\author{
Dennis Gitz ${ }^{1}$ and David Brauer ${ }^{2, *}$ \\ 1 Wind Erosion and Water Conservation Research Unit, Cropping Systems Research Laboratory, \\ USDA-ARS, 3810 4th Street, Lubbock 79415, TX, USA; dennis.gitz@ars.usda.gov \\ 2 Soil and Water Management Research Unit, Conservation and Production Research Laboratory, \\ USDA-ARS, 2300 Experiment Station Drive, PO Drawer 10, Bushland 79012, TX, USA \\ * Correspondence: david.brauer@ars.usda.gov; Tel.: +1-806-356-5769
}

Academic Editor: Jai Vaze

Received: 1 July 2016; Accepted: 15 August 2016; Published: 26 August 2016

\begin{abstract}
The Ogallala Aquifer is an important source of irrigation water on the Texas High plains; however, significant decreases in saturated thickness threaten its future use for irrigation. A better understanding of the roles of playas, ephemeral surface ponds, in aquifer recharge is needed to establish levels of withdrawals that will meet either established desired future conditions or sustainability. In this study, data regarding playa inundation, depth to groundwater, precipitation and land cover from 2001 to 2011 were collected and analyzed to ascertain associations between these characteristics for four study areas on the Texas High plains. Each area covered 40,000-70,000 ha. Three of the study areas in Hockley, Floyd and Swisher counties were chosen because their center contained a playa instrumented to measure weather and depth of inundation. There were 20 distinct inundation events at the three instrumented playas between 2006 and 2010. For each of these inundations, water loss exceeded rates of potential evapotranspiration (ET) by a factor of 1.6-15.7 times, implying that infiltration was occurring. Playa inundation in all four study areas was also assessed by analyzing images from the National Agricultural Imaginary program. Data on depth to groundwater were analyzed from 2000 to 2010 to determine annual changes of stored water. Annual changes in groundwater were weakly associated with surface area of inundated playas in late summer, but was strongly associated with annual rainfall. Rates of infiltration based on playa water loss versus potential ET, and volume of water in playas was more than sufficient to account for annual changes in groundwater. Land use adjoining the playas had less of influence on playa inundation than annual rainfall. These results strengthen the argument that water storage in playas on the Texas High Plains is an important source of water for aquifer recharge.
\end{abstract}

Keywords: surface water; recharge; infiltration; water budget

\section{Introduction}

Llano Estacado is the major geographic feature of the Texas High plains of the USA [1] as a mesa with a very slight increase in elevation from east to west, bounded by escarpments to the east, west and north. Surface hydrological features are unique. There are few draws that transverse the Llano Estacado and these represent the headwaters of the Red and Brazos River systems. Playa wetlands are the most common surface hydrological features of the Llano Estacado. Playas are naturally occurring, circular basins that occur in closed-system watersheds with basin floors containing a soil of higher clay content than the surrounding area [2]. These clay soils create a basin floor that is only slightly permeable to water infiltration which allows the playa to hold water after significant rainfall events. Elevation change between the basin and the surrounding land tends to exceed $1 \mathrm{~m} \mathrm{[3]} \mathrm{and} \mathrm{playa} \mathrm{diameters} \mathrm{vary}$ 
greatly from a few meters to several kilometers [4,5]. It has been estimated that there are approximately 20,000 playas on the Llano Estacado [6,7].

The Llano Estacado has a semi-arid climate with average annual precipitation decreasing from $550 \mathrm{~mm}$ in the northeast to $330 \mathrm{~mm}$ in the southwest [2]. Over $80 \%$ of the annual precipitation occurs from April through September [8]. Potential evapotranspiration (ET) is high, typically exceeding precipitation by a factor of 2 , due to high solar radiation, high daily maximum air temperatures in the summer, low humidity and high wind speeds [9]. These climate conditions create the situation in which playas are dry most of the time [3].

Another important hydrologic feature of the Llano Estacado is the underlying Ogallala Aquifer. The Ogallala Aquifer was formed 2-6 million years ago as water containing sediments were deposited by erosion from a western upland feature. Between 1950 and 1970, the number of acres of cropland irrigated with water from the Ogallala Aquifer increased significantly. By the 1970s, it was apparent that the depth to water was increasing in areas of intensive irrigation because withdrawals were greater than recharge. Scanlon et al. [10] estimated rates of recharge to be less than $15 \mathrm{~mm}$ annually. In addition, no tritium has been found in Ogallala Aquifer water, indicating little or no recharge in the last 50 years since aboveground denotations of nuclear weapons were banned [11].

In retrospective, low recharge of the aquifer in West Texas should have been expected for several reasons. The connection between the source of sediments and water in the western upland no longer exists and surface flows from the mountains tend to be intercepted by the Pecos River valley [1], except in the case of the Canadian River. Second, the low rates of deep infiltration of rainfall are expected because of the high rates of potential ET [9]. The infiltration rate of the Pullman clay loam (Fine, mixed, thermic Torrertic paleustolls) which occupies approximately 1 million ha in Texas High plains has been estimated to be less than $1 \mathrm{~mm} \cdot \mathrm{h}^{-1}[12,13]$. Third, there are no rivers crossing the Llano Estacado that could be a possible source of recharge to the aquifer.

The rate of drawdown of the aquifer in terms of decreases in saturated thickness has been reported to be less than that expected from estimated withdrawals [14]. Such an observation argues in favor of greater rates of recharge. Playa wetlands are hypothesized to serve as a site of aquifer recharge [6,14-18], although the magnitude of their contribution to recharge is still a matter of debate. Gurdak and Roe $[17,18]$ reviewed numerous studies and reported rates of infiltration and/or recharges rates that varied considerably among the reports and within reports. In general, infiltration and/or recharge rates tend to be higher for playas than the area between playas in those studies in which the two environments were compared.

The annulus of the playas on the Texas High plains tend to have lower clay content [19] and therefore thought to be a more likely site for infiltration. However, Scanlon and Goldstein [20] found significant downward movement of chloride and other tracers in the playa's basin, indicating that the water infiltration through the basin's high clay content soil was occurring. The debate regarding the role of the annulus and the playa basin in recharge is unresolved. Zartman et al. [6] classified infiltration rates into two periods, initial rates and long-term rates. Initial rates of infiltration were greater varying from $2490 \mathrm{~mm}$ to $10 \mathrm{~mm} \cdot \mathrm{min}^{-1}$. The long term rates of infiltration ranged from 9996 to $0.004 \mathrm{~mm} \cdot \mathrm{min}^{-1}$.

The exact mechanism by which the playas of the Llano Estacada formed is not fully understand, but their formation occurred when the region was a short grass prairie with little or no slope. Forces thought to be involved in playa creation include: dissolution of underlying carbonates by infiltrating water and downward transport of fine grain minerals and organic matter $[15,16]$. The mechanism leading to the formation of large salt water playas of the extreme southern portion of the Llano Estacado may be distinct from those that led to the formation of fresh water playas [21]. The environmental conditions today are quite different from those present during playa formation. In many areas of the Llano Estacado, the dominant land cover is crop land rather than rangeland [1]. Row crop farming operations can alter the angle and the length of slope of the land draining into a playa basin. In addition, sediments being transported into the playa basin would be expected to be different in composition 
and quantity when the adjoining land is being farmed rather than in rangeland. Researchers [22,23] have hypothesized that changes in the sediment characteristics of playas basin have altered their hydrological functions. Human development (housing, roads, etc.) has altered the size and topology of watersheds contributing to numerous playas. Thus, the hydrological functions of playas on the Llano Estacado may be quite different today than in the past.

A precise understanding of the hydrology of the Llano Estacado is more important today because of changes in water policies enacted by the Texas state assembly between 1995 and 2007. One of the outcomes of these new policies was the implementation of desired future conditions (DFC) for major aquifers throughout the state in the regional water planning process. A DFC for an aquifer is a goal for the aquifer's condition 50 years in the future. These goals can be related to the amount of water in storage or the relationship between water storage and spring outflows. For the Ogallala Aquifer, water plans submitted in September 2010 included DFC for the Ogallala Aquifer that would preserve a significant amount of the water in storage by 2060 [24]. The law dictating the implementation of DFC also has enabled groundwater district to create rules and policies to meet these conditions. Better understanding of the hydrology of the Ogallala Aquifer will be needed to enable groundwater districts and water planning groups established future DFC and policies to meet them. This knowledge includes better information on, but not limited to, the water volume in storage, its spatial and temporal use, locations and quantity of recharge, and the relationship between water storage in playas and the recharge to the aquifer.

In this study, data regarding playa inundation, depth to groundwater, precipitation and land cover from 2001 to 2011 were collected and analyzed to ascertain associations between these characteristics for four areas of the Llano Estacado. Three of the study areas in Hockley, Floyd and Swisher counties were chosen because their centers had a playa containing equipment to measure weather and depth of inundation. The fourth study area was in Lynn County in an area in which recharge to the Ogallala Aquifer is suspected. Each study location occupied an area that comprised 20-30 wells in the Ogallala Aquifer that report the depth to groundwater annually. The study period, 2001-2011, included extreme variations in annual precipitation, from record setting high annual rainfall in 2004 to record setting lows during the drought of 2011. In general, there was a positive association between annual precipitation and annual change in groundwater in storage. However, annual changes in groundwater in storage were not strongly associated with the level of inundation of playas. In addition, many of the presumptive playas based on the presence of higher clay content soils and elevation change were not inundated in images obtained in late summer of 2004, a year of exceptionally high annual rainfall.

\section{Study Area and Data}

The overall area of investigation comprised of the 14 county regions of the Texas High plains covering a large portion of the Llano Estacado (Figure 1). Four study areas were designated; the three study areas in Floyd, Hockley and Swisher counties were created such that the playa instrumented to collect weather and inundation data was near its center. The fourth study was in Lynn County in an area in which increases in water storage in the Ogallala Aquifer during the 2000s were suspected to have occurred. Each study area also encompassed a minimum of 20 wells with depth-to-water data from 1999 to 2012. Rainfall data were obtained for stations located at the Texas' towns of Levelland, Tahoka, Floydada, and Silverton as a measure of precipitation in Hockley, Lynn, Floyd and Swisher county study areas, respectively [25]. Rainfall measurements from these stations were assumed to be representative of the study area and uniform over the study area. The boundaries of the four study areas in Figure 1 are presented in Table 1. All geospatial data layers were projected as Albers Conical Equal Area prior to analyses. Land use in 1980, 1992, 2001 and 2006 were determined by analyses the raster files from the National Land Cover Dataset [26] using ArcMap version 9.3 [27]. Irrigated surface area within each study in 2004 was determined from analyses of the images downloaded from the USDA ARS Ogallala Aquifer Interactive Map Server [7]. 

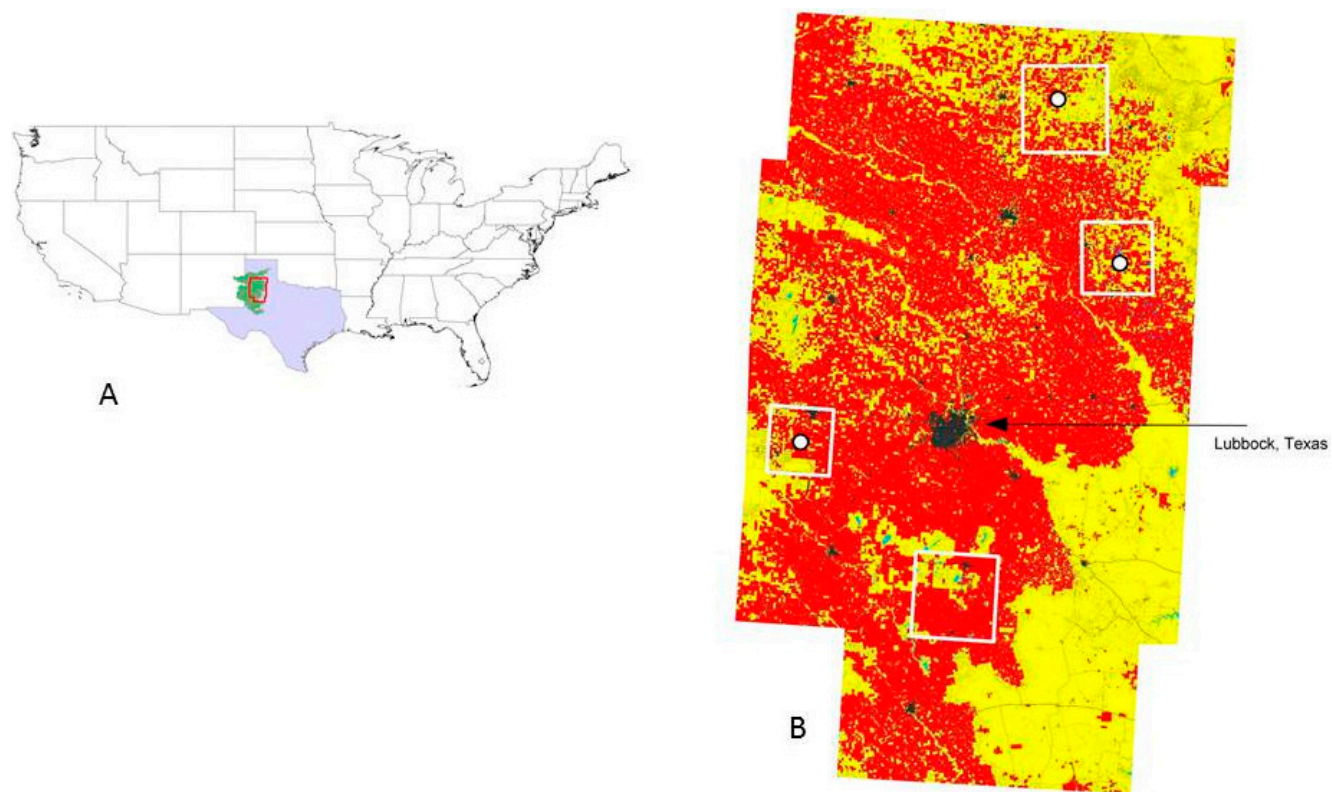

Figure 1. Location of the four study areas on the Llano Estacado in Texas, USA. Panel A shows the borders of the states within the continental USA with the state of Texas being blue. The green area is the Llano Estacado. The area bordered by red lines is the area in panel B. Panel B comprises 14 Texas counties (Borden, Briscoe, Castro, Crosby, Dawson, Floyd, Garza, Hale, Hockley, Lamb, Lubbock, Lynn, Swisher, and Terry). Colors represent different land covers from the 2001 NLCD: red = cropland; yellow = rangeland; black = developed; and blue = wetlands $/$ water. The major developed area identified with the arrow is the city of Lubbock, Texas and is included as a reference point. The four study areas are enclosed by a white border and from north to south the study areas are in Swisher, Floyd, Hockley and Lynn counties, respectively. The three white dots represent the location of the three playas containing equipment to collect weather and inundation data.

Table 1. Geographic boundaries of the four study areas and their areas.

\begin{tabular}{llcccl}
\hline \multirow{2}{*}{ Study Area } & North Bound & South Bound & East Bound & West Bound & Surface Area \\
\cline { 2 - 6 } & & \multicolumn{2}{c}{ Decimal Degrees } & Hectares \\
\hline Floyd & 34.199 & 33.979 & -101.193 & -101.459 & 54,200 \\
Hockley & 33.599 & 33.400 & -102.299 & -102.522 & 44,500 \\
Lynn & 33.198 & 32.948 & -101.685 & -101.976 & 69,500 \\
Swisher & 34.670 & 34.408 & -101.365 & -101.787 & 78,200 \\
\hline
\end{tabular}

Sites of presumptive playas were identified by creating shapefiles of higher clay content soils and excluding those areas in which the change in elevation between the basin and surrounding area was less than $1 \mathrm{~m}$ [1]. Soil maps were obtained from the NRCS Geospatial Gateway [28]. Shapefiles of areas with higher clay content soils were produced by editing the attribute tables of downloaded files. The series of higher clay content soils varied by study area and are summarized in Table 2 .

Inundation of playas was determined using high resolution images of the study areas obtained from the National Agricultural Imaginary Program (NAIP) and downloaded from the internet [28]. These images were routinely obtained between August and September, usually for every other year. During the study period, images were available for 2004, 2005, 2006, 2008 and 2010. NAIP images from 2004 and 2008 were selected for further analyses examining the effects of land use on inundation. These two years were selected because 2004 was high rainfall year and 2008 had annual rainfall that approximated the long term mean. For these additional analyses, the watershed adjacent to presumptive playas was approximated using the basin function in ArcHydro extensions of ArcMap [29]. The dominant land use in each basin adjacent to presumptive playas was determined from the 2006 National Land Cover Dataset. 
Table 2. Series of higher clay content soils in each of the four study areas and surface area of presumptive playas.

\begin{tabular}{|c|c|c|c|c|}
\hline \multirow{2}{*}{ Soil Series } & \multicolumn{4}{|c|}{ Study Area } \\
\hline & Floyd & Hockley & Lynn & Swisher \\
\hline Chapel Clay Loam & & Yes & & \\
\hline Lofton Clay Loam & & Yes & Yes & \\
\hline Olton Clay Loam & & Yes & Yes & \\
\hline Ranco Clay & & Yes & Yes & \\
\hline Randall Clay & Yes & & & Yes \\
\hline Sparenburg Clay & & Yes & Yes & \\
\hline Presumptive Playas Surface Area (ha) & 2600 & 850 & 1880 & 2740 \\
\hline
\end{tabular}

Depth to water data from the wells in the study areas were obtained from the Texas Water Development Board via the USDA ARS Ogallala Aquifer Interactive Map Server [7]. Depth to-water measurements from November of one year until end of the February of the following year were used as measures of year-end levels. Depth-to-water rasters for each year were created from point files of the depth of water data using interpolation operations with the Kriging algorithm in the toolbox of ArcMap [27]. Changes in aquifer storage were calculated by differences between annual depth-to-water rasters using the math operations in ArcMap [27]. Regression analyses and chi-square comparisons were performed using PROC REG and FREQ, respectively [30].

\section{Materials and Methods}

One playa in Floyd, Hockley and Swisher County with cropland as the dominant land cover in the adjoining watershed was selected to receive an instrument package to track precipitation and water level, and to provide variables for calculation of free water evaporation (Table 1 and Figure 1). Sensors for measuring air speed (014A Anemometer, Met One Instruments, Grants Pass, OR, USA), temperature and humidity (HMP50-L Temperature and Relative Humidity Sensor, Campbell Scientific Inc., Logan, UT, USA), precipitation (TR-525M tipping bucket rainfall sensor, Texas Electronics Inc., Dallas, TX, USA), and water depth (260-700 Ultrasonic Snow Depth Sensor, NovaLynx Corp., Grass Valley, CA, USA) were mounted on a horizontal boom at $2 \mathrm{~m}$ above the playa bottom. A $1 \mathrm{~m} \times 1 \mathrm{~m}$ steel plate was placed directly below the ultrasonic depth sensor to prevent weed growth and provide a clean echo reflection surface. Radiation as both global downwelling solar radiation (LI-200 solid state pyranometer, LiCor Inc., Lincoln, NE, USA) and net solar radiation (NR Lite2 thermopile radiometer, Kipp \& Zonen USA Inc., Bohemia, NY, USA) were measured with sensors placed on the primary tripod or on a remotely mounted $2 \mathrm{~m}$ mast. All data were recorded as $15 \mathrm{~min}$ averages and exported weekly with a digital cellular modem.

\section{Results}

As in Table 3, the soil series at the bottom of the playas in Swisher and Floyd counties was classified as Randall Clay (Fine montmorillonitic, thermic udic pellusterts) [25], whereas the bottom of the playa in Hockley County was classified as Ranco Clay, (Fine, smectitic, Thermic Ustic Epiaquerts) [31]. Both soils were described as being poorly drained with a capacity to transmit water being less than $1.5 \mathrm{~mm} \cdot \mathrm{h}^{-1}$. The beginning date of an inundation period was defined as the day in which depth of water was maximal after a rain event. The ending date was defined as the next day with measureable rainfall, the depth of water declined below $50 \mathrm{~mm}$ or obstruction of the sensor by vegetation. Depth of water observations from 7:00 a.m. were used as a measure of inundation. Daily rates of potential ET were calculating from daily minimum and maximum air temperature, and daily mean values for relative humidity, and wind velocity using DailyET calculator V3.0 [32] and the penman-Monteith method. Previous research has estimated evaporative losses from temporary bodies of water by similar methods [33-36]. Daily potential ET values were summed for the days in the inundation period to 
calculation a cumulative potential ET loss. Other methods for calculating evapotranspiration were explored using the available climate data including Priestley-Taylor, and Bushland Reference ET calculator [37]; however, the values for daily ET were within 3\% of those calculated by the Daily ET calculator.

Table 3. Characteristics of the playa in which instruments were deployed to collect local weather and water inundation data.

\begin{tabular}{ccccc}
\hline County & Latitude & Longitude & Soil Type of Playa Basin & Data Collection Started \\
\hline Floyd & 34.073 & -101.315 & Randall Clay & $12 / 17 / 2005$ \\
Hockley & 33.494 & -102.408 & Ranco Clay & $12 / 21 / 2005$ \\
Swisher & 34.541 & -101.570 & Randall Clay & $12 / 23 / 2005$ \\
\hline
\end{tabular}

\subsection{Characteristics of Playa Inundation Events}

From the time that data collection instruments were deployed until December 31, 2010, seven, five and eight inundation events were recorded at the playas in Floyd, Hockley and Swisher counties, respectively (Table 4). The period of inundation in days and the initial water depth varied greatly among events and playas. In general, the loss of water from the playa as measured by changes in depth of inundation exceeded the loss of water as estimated by changes in cumulative potential ET as evident by the ratio of water loss to potential ET exceeding 1.0 for every inundation event. The ratio of apparent water loss to cumulative potential ET averaged 2.2, 8.7 and 2.8 for the playa in Floyd, Hockley and Swisher counties, respectively. It is interesting to note that the ratio of water lost to cumulative potential ET was greatest for the Hockley county playa which had Ranco clay as its basin, compared to Randall clay for the other two playas. Other researchers [33-36] have applied a similar mass balance approach to water loss from playa in such a way that the water loss not attributed to potential ET was assumed to be infiltration. If the underlying assumptions are corrected, a ratio of water lost to potential ET greater than 1.0 indicates that infiltration was a significant mechanism. Thus, these results support the hypothesis that playas can be a source of water for infiltration.

Table 4. Characteristics of playa Inundation Events. Potential evapotranspiration (PET) was calculated by the weather data collected at the playa.

\begin{tabular}{|c|c|c|c|c|c|c|}
\hline \multirow{2}{*}{$\begin{array}{l}\text { Playa } \\
\text { Location }\end{array}$} & \multicolumn{2}{|c|}{ Inundation Period } & \multicolumn{2}{|c|}{ Water Depth (mm) } & \multirow{2}{*}{$\begin{array}{l}\text { Cumulative } \\
\text { PET }\end{array}$} & \multirow{2}{*}{$\begin{array}{l}\text { Water } \\
\text { Loss/PET }\end{array}$} \\
\hline & Starting Date & Ending Date & Starting & Ending & & \\
\hline \multirow{7}{*}{ Floyd } & $9 / 5 / 2006$ & $9 / 11 / 2006$ & 262.9 & 232.0 & 17.7 & 1.8 \\
\hline & $9 / 12 / 2006$ & $10 / 7 / 2006$ & 238.6 & 51.4 & 89.5 & 2.1 \\
\hline & $10 / 15 / 2006$ & $11 / 14 / 2006$ & 163.5 & 21.0 & 80.2 & 1.8 \\
\hline & $3 / 29 / 2007$ & $5 / 7 / 2007$ & 278.9 & 93.5 & 117.4 & 1.6 \\
\hline & $8 / 29 / 2007$ & $10 / 9 / 2007$ & 1033.0 & 765.5 & 98.2 & 2.7 \\
\hline & $4 / 15 / 2010$ & $6 / 25 / 2010$ & 1336.0 & 707.3 & 275.9 & 2.3 \\
\hline & $6 / 27 / 2010$ & $12 / 6 / 2010$ & 1382.0 & 112.0 & 434.9 & 2.9 \\
\hline \multirow{5}{*}{ Hockley } & $3 / 26 / 2007$ & $4 / 18 / 2007$ & 630.5 & 8.8 & 67.6 & 9.2 \\
\hline & $5 / 3 / 2007$ & $5 / 8 / 2007$ & 112.3 & 4.9 & 23.4 & 4.6 \\
\hline & $9 / 9 / 2007$ & $9 / 14 / 2007$ & 130.3 & 1.4 & 8.2 & 15.7 \\
\hline & $5 / 8 / 2008$ & $6 / 10 / 2008$ & 1186.0 & 24.8 & 189.5 & 6.1 \\
\hline & $6 / 21 / 2009$ & $7 / 3 / 2009$ & 424.3 & 32.1 & 49.7 & 7.9 \\
\hline \multirow{8}{*}{ Swisher } & $6 / 1 / 2006$ & $7 / 30 / 2006$ & 883.0 & 8.6 & 216.1 & 4.0 \\
\hline & $8 / 31 / 2006$ & $10 / 6 / 2006$ & 1254.0 & 971.0 & 115.6 & 2.4 \\
\hline & $5 / 25 / 2009$ & $6 / 13 / 2009$ & 375.4 & 273.0 & 42.6 & 2.4 \\
\hline & $6 / 21 / 2009$ & $6 / 28 / 2009$ & 872.0 & 793.4 & 22.9 & 3.4 \\
\hline & $6 / 30 / 2009$ & $7 / 17 / 2009$ & 899.0 & 727.7 & 62.3 & 2.8 \\
\hline & $8 / 16 / 2009$ & $10 / 19 / 2009$ & 672.0 & 183.9 & 138.2 & 3.5 \\
\hline & $10 / 23 / 2010$ & $11 / 11 / 2010$ & 475.4 & 344.2 & 65.8 & 2.0 \\
\hline & $11 / 15 / 2010$ & $12 / 31 / 2010$ & 352.0 & 107.8 & 108.6 & 2.2 \\
\hline
\end{tabular}




\subsection{Characteristics of the Four Study Areas}

Land cover changes from 1980 to 2006 in the four study areas were assessed by analyzing the National Land Cover Data (Table 5). In the four study areas, cropland and rangeland constituted the vast majority of the surface area. In all four studies, there was a general trend from 1980 to 2001 that the percentage of the surface area as cropland decreased with concomitant increase in rangeland. As an example, in the Floyd county study, cropland and rangeland occupied $93.2 \%$ and $3.2 \%$ of the surface, respectively, in 1980, compared to $48.7 \%$ and $43.7 \%$ in 2001 . The distribution of surface area between cropland and rangeland changed little between 2001 and 2006. Irrigated acreage in 2004 as a fraction of the surface area varied from a low of $2.8 \%$ in the Swisher county study area to a maximum of $16.5 \%$ in the Hockley county study area.

Table 5. Land use characteristics from 1980 to 2006 in the four study areas.

\begin{tabular}{|c|c|c|c|c|c|c|}
\hline \multirow{3}{*}{ County } & \multirow{3}{*}{ Land Use } & \multicolumn{5}{|c|}{ Year } \\
\hline & & 1980 & 1992 & 2001 & 2004 & 2006 \\
\hline & & \multicolumn{5}{|c|}{$\%$ of Surface Area } \\
\hline \multirow{3}{*}{ Floyd } & Cropland & $93.2^{1}$ & 88.0 & 48.7 & & 48.6 \\
\hline & Rangeland & 3.2 & 8.6 & 43.7 & \multirow{3}{*}{5.9} & 41.9 \\
\hline & Irrigated & & & & & \\
\hline \multirow{3}{*}{ Hockley } & Cropland & 79.2 & 73.4 & 53.5 & & 54.5 \\
\hline & Rangeland & 17.6 & 24.3 & 34.4 & \multirow{3}{*}{16.5} & 33.3 \\
\hline & Irrigated & & & & & \\
\hline \multirow{3}{*}{ Lynn } & Cropland & 80.3 & 76.5 & 67.5 & & 67.6 \\
\hline & Rangeland & 17.6 & 22.3 & 23.8 & \multirow{3}{*}{4.8} & 23.5 \\
\hline & Irrigated & & & & & \\
\hline \multirow{3}{*}{ Swisher } & Cropland & 73.2 & 69.0 & 37.2 & & 37.2 \\
\hline & Rangeland & 24.7 & 30.2 & 56.0 & \multirow[b]{2}{*}{2.8} & 55.7 \\
\hline & Irrigated & & & & & \\
\hline
\end{tabular}

The mean depth to water for the Ogallala Aquifer in 2000 was least for the wells in the Lynn county study area, averaging $8.3 \mathrm{~m}$ (Table 6). A well in the Lynn County study reported a depth to water of only $1 \mathrm{~m}$ between 2000 and 2011. The mean depth to water for the Ogallala Aquifer in 2000 was greatest in Floyd county study area, averaging $56.6 \mathrm{~m}$. The average specific yield ranged from under $11 \%$ in the Lynn and Hockley county study areas to $18.6 \%$ in the Floyd county study area.

Table 6. Characteristics of the Ogallala Aquifer under the four study areas.

\begin{tabular}{ccccc}
\hline \multirow{2}{*}{ Study Area } & $\begin{array}{c}\text { Number of } \\
\text { Reporting Wells } \mathbf{1}^{*}\end{array}$ & $\begin{array}{c}\text { Mean Depth to } \\
\text { Water in 2000 }\end{array}$ & $\begin{array}{c}\text { Range of Depth to } \\
\text { Water 2000 to 2011 }\end{array}$ & $\begin{array}{c}\text { Mean Specific } \\
\text { Yield }\end{array}$ \\
\cline { 3 - 5 } & & \multicolumn{2}{c}{ Meters } & \% \\
\hline Floyd & 22 & 56.6 & $33-86$ & 18.6 \\
Hockley & 23 & 46.1 & $35-65$ & 10.9 \\
Lynn & 24 & 8.3 & $1-15$ & 10.8 \\
Swisher & 22 & 40.2 & $21-53$ & 15.8 \\
\hline
\end{tabular}

${ }^{1}$ Number of wells in the study area that report depth to water to Texas Water Development Board from 2000 to 2011 .

Annual rainfall varied considerably between 2000 and 2011 (Figure 2). Annual rainfall at Levelland, Tahoka, Silverton and Floydada averaged 498, 517, 558 and $530 \mathrm{~mm}$, respectively, from 1960 to 2010. Annual rainfall set record high measurements in 2004 and record lows in 2011 at all four weather stations. Annual rainfall was near average in 2008. 


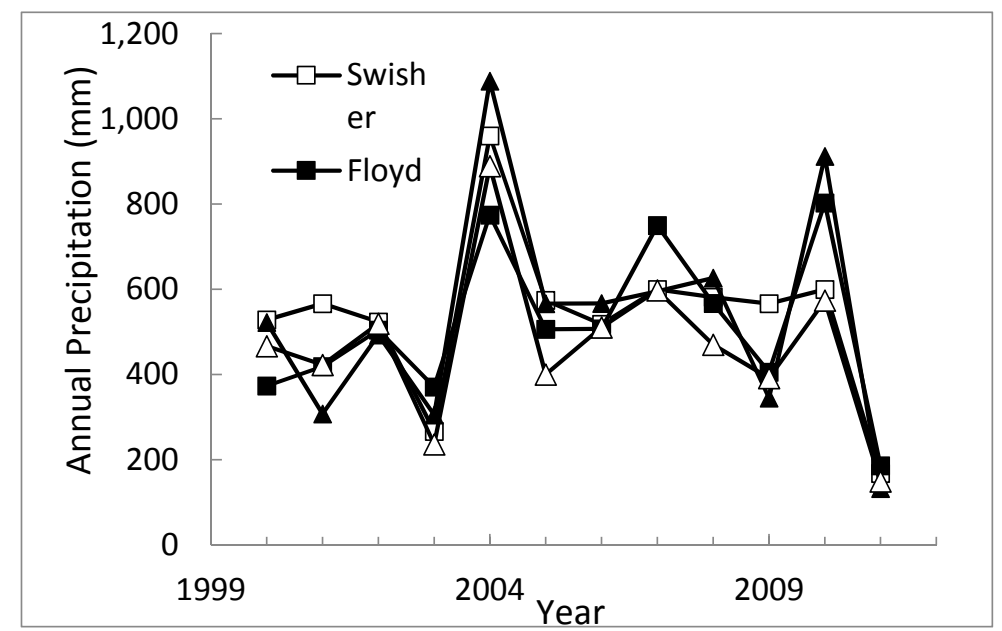

Figure 2. Annual precipitation from 2000 to 2011 at the weather stations located near the Floyd, Hockley, Lynn and Swisher county study areas, in the towns of Floydada, Levelland, Tahoka and Silverton, respectively. The mean annual rainfall from 1960 to 2010 was 498, 517, 558, and 530 mm for Levelland, Tahoka, Silverton and Floydada, respectively.

Surface area for playa water was highest in 2004 from 2003 to 2010 in all four study areas (Table 7). Playa water surface area in 2010 in Lynn and Floyd approached that found in 2004. Annual rainfall in 2010 at the weather stations near the Lynn and Floyd county study areas approached that in 2004. The surface area of playa water in 2004, 2006 and 2010 in the Floyd county study area exceeded the surface area of presumptive playas, 2600 ha. In 2004 and 2010, the surface area of playa water approached the surface area of presumptive playas in the Lynn county study area, which was estimated to be 1880 ha. However, inundation was not observed over all of the presumptive playas (data not shown). Surface area of playa water in the Hockley and Swisher county study areas never approached the surface area of presumptive playas, which was estimated to be 850 and 2700 ha in the Hockley and Swisher county study areas.

Table 7. Changes in groundwater in the Ogallala Aquifer under the four study areas from 2001 to 2011 and the surface area of playa water in late summer in the four study areas from 2003 to 2010.

\begin{tabular}{|c|c|c|c|c|c|c|c|c|}
\hline \multirow{2}{*}{$\begin{array}{c}\text { Study Area } \\
\text { Year }\end{array}$} & \multicolumn{2}{|c|}{ Floyd County } & \multicolumn{2}{|c|}{ Hockley County } & \multicolumn{2}{|c|}{ Lynn County } & \multicolumn{2}{|c|}{ Swisher County } \\
\hline & $\begin{array}{l}\text { Change } \\
\text { Gwater }{ }^{1}\end{array}$ & Area $^{2}$ & $\begin{array}{l}\text { Change } \\
\text { Gwater }{ }^{1}\end{array}$ & Area $^{2}$ & $\begin{array}{l}\text { Change } \\
\text { Gwater }^{1}\end{array}$ & Area $^{2}$ & $\begin{array}{l}\text { Change } \\
\text { Gwater }{ }^{1}\end{array}$ & Area $^{2}$ \\
\hline & $\mathrm{m}^{3}$ & ha & $\mathrm{m}^{3}$ & ha & $\mathrm{m}^{3}$ & ha & $\mathrm{m}^{3}$ & ha \\
\hline 2001 & $-23,100$ & & $-11,400$ & & $-32,800$ & & 49,800 & \\
\hline 2002 & -4800 & & 7500 & & $-23,500$ & & 19,900 & \\
\hline 2003 & $-28,800$ & & $-28,300$ & 8 & $-26,700$ & 665 & $-66,900$ & \\
\hline 2004 & 17,600 & 3381 & 3500 & 254 & 169,900 & 1761 & 48,300 & 1527 \\
\hline 2005 & -4000 & 583 & $-6,900$ & 54 & -9900 & 645 & 7800 & 954 \\
\hline 2006 & $-13,300$ & 3055 & $-32,200$ & 48 & -9400 & 372 & $-67,182$ & 846 \\
\hline 2007 & 14,200 & & 20,800 & & 59,500 & & -1300 & \\
\hline 2008 & $-11,400$ & 817 & $-34,400$ & 59 & 14,600 & 831 & $-13,000$ & 564 \\
\hline 2009 & -9500 & & $-23,100$ & & $-47,500$ & & 13,000 & \\
\hline 2010 & 9400 & 3029 & 1400 & 46 & 134,800 & 1488 & 4400 & 562 \\
\hline 2011 & $-59,800$ & & $-36,600$ & & $-115,900$ & & 3400 & \\
\hline
\end{tabular}

${ }^{1}$ Change Gwater $=$ Annual change in Groundwater; ${ }^{2}$ Surface area of playa water as determined from NAIP images acquired in late summer.

In general, playa water surface area in late summer was only weakly correlated with annual precipitation. Playa water surface area (ha) $=-230.9+1.94$ (annual precipitation, $\mathrm{mm}$ ) with $\mathrm{F}$-value 
for the model of $3.96(p=0.06)$ and R-square of 0.16 . Inspection of these data indicates that the relationship between playa water surface area and annual precipitation differed among the four study areas. Even within each study area, the relationship between annual precipitation and playa surface was fairly weak (data not shown). A weak association between annual precipitation and playa inundation may indicate that inundation occurred more frequently with a large volume rainfall event or a cluster of medium to large rainfall events. Such a conclusion is consistent with the results of Jones et al. [38] that concluded that runoff from Texas High Plain agricultural systems was more correlated with the volume of the storm triggering the event than other factors.

On the other hand, calculated changes in groundwater were positively correlated with annual precipitation (Table 8). Using data from all four studies, changes in groundwater were strongly correlated with annual rainfall with R-square of 0.516 and F-value significant at $p<0.001$. The relationship between annual rainfall was strongest with the data from the Lynn County study $(\mathrm{F}$-value $=104.98, p<0.001)$ but there was barely a trend for the data from the Swisher County study area (F-value $=3.37, p<0.10$ ). The Y-intercepts for the regression between annual rainfall and changes in groundwater storage in the Ogallala Aquifer were negative in all cases with the magnitude of the value being least with the data from the Lynn County study area. The slope of relationships between annual rainfall and changes in groundwater was greatest for the data from the Lynn County study area, with the slopes for the other three study areas being within the standard errors of each other. The difference in the relationship between annual rainfall and changes in groundwater storage may reflect a difference in the depth to water since this parameter was different for the Lynn county study area compared to the other three areas.

Table 8. Regression equations predicting changes in groundwater in the Ogallala Aquifer as a function of annual rainfall for each of the four study areas and a data set combining the results from the four study areas.

\begin{tabular}{ccccc}
\hline Study Area & Y-Intercept & Slope & R-Square & F-Value \\
\hline Floyd & $-49,600 \pm 5700$ & $0.000147 \pm 0.000017$ & 0.870 & $60.21^{* * *}$ \\
Hockley & $-43,000 \pm 12,900$ & $0.000145 \pm 0.000058$ & 0.414 & $6.36^{*}$ \\
Lynn & $-143,900 \pm 16,700$ & $0.000411 \pm 0.000040$ & 0.920 & $104.98^{* * *}$ \\
Swisher & $-53,200 \pm 30,900$ & $0.000122 \pm 0.000079$ & 0.273 & $3.37^{+}$ \\
All & $-71,300 \pm 11,400$ & $0.000212 \pm 0.000032$ & 0.516 & $44.81^{* * *}$ \\
\hline$+* * * *$ & denotes that the F-value for the model was significant at $p<0.10,0.05$, and 0.001, respectively.
\end{tabular}

\subsection{Effects of Land Use on Inundation of Areas with High Clay Soils}

Data from the NAIP images from 2004 and 2008 were analyzed to determine the effects of land use in the watershed adjoining a presumptive playa. In 2004, when annual rainfall exceeded long-term means, approximately half of presumptive playas were inundated (Table 9). The percentage of presumptive playas being inundated in the summer of 2004 was not affected by the predominant land use in three of the four study areas. There was an increased likelihood of a presumptive playa being inundated only in the Hockley County study area in 2004 when the dominant land use in the watershed was cropland, $60.3 \%$ inundation compared to $37.8 \%$ inundation when the watershed was mainly rangeland. In 2008, a year of near average annual rainfall, the overall frequency of inundation of presumptive playas was less than $30 \%$. These results indicate that presumptive playas were more likely to be inundated in late summer during a year with high annual rainfall (2004) compared to a year with near average annual rainfall (2008). However, there was a greater tendency for the land use to affect the likelihood that a presumptive playa would be inundated in years of average annual rainfall. In three of the four study areas (Floyd, Hockley and Lynn counties), the percentage of presumptive playas inundated in watershed dominated by cropland was greater than those in watersheds dominated by rangeland. The lack of an effect of land use on the likelihood of a presumptive playa being inundated in the Swisher County study area may be related to the fact that this area had the least area of irrigation. 
Table 9. Frequency of the inundation of presumptive playas based on high clay content soils and elevation changes as affected by adjoining land use and year. Locations of presumptive playas were identified by areas with soils with higher clay content and having an elevation change of greater than $1 \mathrm{~m}$. Images from the summer of 2004 and 2008 were analyzed to determine the effects of predominant land use in a year with high annual rainfall (2004) compared to those in a year with average annual rainfall (2008). The dominant land use in the watershed was determined from 2006 NLCD.

\begin{tabular}{|c|c|c|c|c|}
\hline \multirow{3}{*}{ Study Area } & \multicolumn{2}{|c|}{2004} & \multicolumn{2}{|c|}{2008} \\
\hline & Rangeland & Cropland & Rangeland & Cropland \\
\hline & \multicolumn{2}{|c|}{$\%$ of Playas Inundated } & \multicolumn{2}{|c|}{$\%$ of Playas Inundated } \\
\hline Floyd & 38.3 & $43.0^{\mathrm{ns}}$ & 14.6 & $26.2^{+}$ \\
\hline Hockley & 37.8 & $60.3 *$ & 14.1 & $29.2 *$ \\
\hline Lynn & 56.5 & $54.7^{\mathrm{ns}}$ & 6.7 & $23.4 *$ \\
\hline Swisher & 40.2 & $46.0^{\mathrm{ns}}$ & 23.0 & $23.7^{\mathrm{ns}}$ \\
\hline
\end{tabular}

$\mathrm{ns},+$, and * indicate the chi-square for testing the effects of land use on the percentage of suspected playas being inundated within a year and study area were not significant $(p>0.10)$, significant at $p<0.10$ and $p<0.05$, respectively.

\section{Discussion}

Between 2001 and 2011, analyses of the depth to water from the four study areas was able to detect annual changes in the amount of groundwater in storage in the underlying Ogallala Aquifer (Table 7). Annual changes in groundwater ranged from a decrease of approximately $116,000 \mathrm{~m}^{3}$ of water to an increase of approximately $170,000 \mathrm{~m}^{3}$. Annual changes in groundwater were positively correlated with the annual rainfall (Table 8). Although the slopes of the regression equations between annual rainfall and changes in groundwater tended to be significantly different from zero, their values indicate that less than $0.04 \%$ of the annual rainfall was affecting groundwater storage.

This study was undertaken as a part of a larger series of studies to better understand the possible role of playas in changes in water storage in the Ogallala Aquifer underlying western Texas. A linchpin in these studies has been the deployment in 20 playas throughout the Llano Estacado instruments to measure inundation and local weather conditions. This study utilized data from only three of these 20 playas.

One of the critical questions was the proportion of water loss from inundated playas that was due to either ET or infiltration. Others using a mass balance approach have assigned the loss of water from playas not accounted for by potential ET as infiltration [33-36]. The loss of water in excess of potential ET from the three playas which would include substantial infiltration was occurring during the inundation events in 2006 through 2010. Apparent rates of infiltration were calculated to be 2-20 mm day $^{-1}$ (Table 4). However, downward movement of soil would be greater than the loss of water because the porosity of the soil is not $100 \%$, but some fraction. [25]. Therefore, the maximum downward movement of the water through the playa basin soil could be as much as $40 \mathrm{~mm} \cdot \mathrm{day}^{-1}$, or $15 \mathrm{~m}$ annually.

The above observed rates of apparent infiltration are sufficient to transport water beyond the $2 \mathrm{~m}$ depth that is a typical rooting zone [25]. Once water has reached the underlying Blackwater draw and its associated caliche, the rate of infiltration should be significantly greater. Gile [39] determined infiltration rates of underlying calcium rich horizons to be from 0.1 to approximately $150 \mathrm{~mm} \cdot \mathrm{h}^{-1}$ or $130 \mathrm{~m} \cdot$ year $^{-1}$. Infiltration rates of caliche have been estimated to be similar $150 \mathrm{~mm} \cdot \mathrm{h}^{-1}$ or $130 \mathrm{~m}$ annually $[39,40]$. Therefore, it appears that the rates of infiltration through the playa soil and the underlying Blackwater Draw are sufficient for water to reach the caprock above the Ogallala Aquifer within a year.

Another aspect that needs to be evaluated to understand the potential role of playas in annual fluctuations in the depth to water for the Ogallala Aquifer is the volume of water stored in the playas. The characteristics of water storage in playas in Floyd County are presented here as being typical 
of the four study areas. If the levels of inundation (approximately $2 \mathrm{~m}$ ) for the two events in 2010 (Table 4) for the instrumented playa in the Floyd county study area reflected the general trend for that year, then 3000 ha of playa surface area (Table 7) would contain approximately $60,000,000 \mathrm{~m}^{3}$ of water. Similar values were obtained by converting surface area of playa inundation from the NAIP to volume using changes in elevation from digital elevation maps and assuming the volume of the playa could be approximated by half of an ellipsoid (data not shown). This volume of water would represent approximately $15 \%$ of the annual precipitation, and several times larger than the observed annual change in groundwater for the study area in 2010. These results suggest that there is sufficient water in storage in the playa lakes to affect groundwater storage.

The above analyses did not consider the impact of withdrawals on the water storage in the study areas. All four study areas are within the High Plains Underground Water District No. 1. This water district is implementing rules to restrict water pumping to a maximum of $1150 \mathrm{~mm} \cdot \mathrm{ha}^{-1}$ annually [41], a reduction from the estimated pumping rate during the study period of $1500 \mathrm{~mm} \cdot \mathrm{ha}^{-1}$ annually. Using the Floyd county study as an example, there is still sufficient water in storage in playas to account for the changes in water storage in the Ogallala Aquifer. For example, in 2010, the total amount of water estimated to be in playas in August to September was 60,000,000 $\mathrm{m}^{3}$. The change in groundwater was $9000 \mathrm{~m}^{3}$. The amount estimated for withdrawals for irrigation was $48,000,000 \mathrm{~m}^{3}$.

The above calculations assumed that water loss from lateral flows within the soil or the underlying Blackwater Draw was minimum. The clay content of the playa bottom soils would have a greater matrix potential, thus preventing lateral water movement to the lower clay content soils in the areas adjoining the playa. The relatively high infiltration rate of the caliche [40] beneath the soil would encourage downward water movement over that of lateral flow.

To summarize for the Llano Estacado, there appears to be sufficient rates of water infiltration and water volume in playas to account for increases in groundwater that occurred from 2001 to 2010. Therefore, these data suggest that water stored in playas has a role in annual variations in groundwater storage and presumably recharge for the Ogallala Aquifer under the Llano Estacado.

Other results presented here indicate that not all presumptive playas, that is, areas with higher clay content and an elevation change of greater than $1 \mathrm{~m}$ became inundated even in 2004 when historically high annual rainfall amounts were recorded (Table 9). A majority of the presumptive playas were not inundated in late summer in 2008, a year with near average annual rainfall. Similarly, Johnson et al. [42] found that nearly one-third of 221 presumptive playas had no water in January from 2001 to 2010. In addition, further analyses by Johnson et al. [42] indicated that previous year's rainfall was an important factor determining whether or not a playa would be inundated in January.

At least two reasons could account for the lack of inundation of presumptive playas. First, the soil classification leading to an area being classified with a higher clay content soil could be inaccurate. Many of the soil series classification were based on aerial mapping techniques rather than on site evaluations. Second, the area containing the higher clay content soils or immediately adjoining area has been altered leading to a situation in which runoff no longer accumulates over the presumptive playa.

The effect of adjoining land use on playa inundation was most profoundly seen in the data from 2008. Playas adjoining cropland in three of the four study areas were significantly more likely to be inundated than playas with adjoining rangeland (Table 9). There was no difference in the frequency of inundation in 2008 for the Swisher County study area. Differences in irrigation may have been one factor responsible for the different effect in the Swisher County study area since it had the least amount of irrigation (Table 5). In addition, the percentage of suspected playas being inundated in Swisher County study area in 2008 was similar to that observed in the other three study areas adjoining cropland. The effect of land use adjoining the playa on the likelihood of inundation in 2004 was less, with only one study area having a significant difference in percentage of inundation (Table 9). Since trends in the effect of land use adjoining the playa were more apparent in the year of higher annual rainfall, rainfall appeared to be a greater determinant of inundation than adjoining land use and its impact on runoff. These results are consistent with the findings of Johnson et al. [42] in which 
these authors reported that previous year's rainfall but not the fraction of the watershed in rangeland affected inundation in January.

\section{Summary}

In this study, data regarding playa inundation, loss of water from inundated playas by ET and infiltration, depth to groundwater, precipitation and land cover from 2001 to 2011 were analyzed for four study areas on the Texas High plains. Each area covered 40,000-70,000 ha. Three of the study areas in Hockley, Floyd and Swisher counties were chosen because their center contained a playa instrumented to measure weather and depth of inundation. There were 20 distinct inundation events at the three instrumented playas between 2006 and 2010. For each of these inundations, water loss exceeded rates of potential ET by a factor of 1.6-15.7 times, implying that infiltration was occurring. Playa inundation in all four study areas was also assessed by analyzing images from the NAIP. Data on depth to groundwater were analyzed from 2000 to 2010 to determine annual changes of stored water, and calculated changes in annual storage varied from significant depletion to significant increases. Annual changes in groundwater were strongly associated with annual rainfall and weakly associated with surface area of inundated playas in late summer. Rates of infiltration based on playa water loss versus potential ET, and volume of water in playas was more than sufficient to account for annual changes in groundwater. Land use adjoining the playas had less influence on playa inundation than annual rainfall. These results strengthen the argument that water storage in playas on the Texas High plains is an important source of water for aquifer recharge. However, changes in groundwater storage represented a very small fraction $(<0.1 \%)$ of the annual precipitation.

Acknowledgments: The U.S. Department of Agriculture (USDA) prohibits discrimination in all its programs and activities on the basis of race, color, national origin, age, disability, and where applicable, sex, marital status, familial status, parental status, religion, sexual orientation, genetic information, political beliefs, reprisal, or because all or part of an individual's income is derived from any public assistance program. (Not all prohibited bases apply to all programs.) Persons with disabilities who require alternative means for communication of program information (Braille, large print, audiotape, etc.) should contact USDA's TARGET Center at (202) 720-2600 (voice and TDD). To file a complaint of discrimination, write to USDA, Director, Office of Civil Rights, 1400 Independence Avenue, S.W., Washington, D.C. 20250-9410, or call (800) 795-3272 (voice) or (202) 720-6382 (TDD). USDA is an equal opportunity provider and employer.

The use of trade, firm, or corporation names in this web site is for the information and convenience of the reader. Such use does not constitute an official endorsement or approval by the United States Department of Agriculture or the Agricultural Research Service of any product or service to the exclusion of others that may be suitable.

Author Contributions: Dr. D. Gitz collected the data on playa inundation and weather. Dr. D. Brauer assembled and analyzed the other data. Dr. Brauer drafted the initial version of the manuscript. Dr. Gitz revised the manuscript.

Conflicts of Interest: This research was supported by the Ogallala Aquifer Program, a research and education consortium consisting of ARS-USDA, Kansas State University, Texas A\&M AgriLife/Texas A\&M University, Texas Tech University and West Texas A\&M University.

\section{Abbreviations}

DFC, Desired future conditions; NAIP, National Agricultural Imaginary Program; ET, evapotranspiration.

\section{References}

1. Spearing, D. Roadside Geology of Texas. Mountain Press Publishing Company: Missoula, MT, USA, 1991; pp. 353-357.

2. Bolen, E.G.; Smith, L.M.; Schramm, H.L., Jr. Playa lakes: Prairie wetlands of the southern High plains. Bioscience 1989, 39, 651-623. [CrossRef]

3. Haukos, D.A.; Smith, L.M. Ecology of Playa Lakes. Fish Wild Leaflet; Fish Wild Serv: Washington, DC, USA, 1992; pp. 1-7.

4. Johnson, W.D. The High Plains and Their Utilization. 21st Ann Rep, 1901; 1890-1900; US Geological Survey: Reston, VA, USA, 1990. Part 4. pp. 601-741. 
5. Guthery, F.S.; Bryant, F.C. Status of playas in the southern Great plains. Wildl. Soc. Bull. 1982, 10, 309-317.

6. Zartman, R.E.; Evans, P.W.; Ramsey, R.H. Playa lakes on the Southern High plains in Texas: Reevaluating infiltration. J. Soil Water Conserv. 1994, 49, 299-301.

7. Center for Geospatial Technology at Texas Tech University. Wetlands of the Texas High Plains. 2014. Available online: http:/ / mapserver.gis.ttu.edu/OgallalaOAP/ (accessed on 15 September 2014).

8. Gustavson, T.C.; Vance, T.H.; Hovorka, S.D. Origin and Development of Playa Basins, Sources of Recharge to the Ogallala Aquifer, Southern High Plains, Texas and New Mexico 1995; Report 229; Bureau Economic Geology, The University of Texas at Austin: Austin, TX, USA, 1995; p. 228.

9. Steiner, J.L.; Howell, T.A.; Schneider, A.D. Lysimetric evaluation of daily potential evapotranspiration models for grain sorghum. Agron. J. 1991, 83, 240-247. [CrossRef]

10. Scanlon, B.R.; Reedy, R.C.; Baumhardt, R.L.; Strassberg, G. Impact of deep plowing on groundwater recharge in a semiarid region: Case study, High Plains, Texas. Water Resour. Res. 2008, 44, W00A10. [CrossRef]

11. Reedy, R.C.; Davidson, S.; Crowell, A.; Gates, J.; Akasheh, O.; Scanlon, B.R. Groundwater Recharge in Central High Plains of Texas: Roberts and Hemphill Counties; Report to TWDB; Austin, TX, USA, 2008; p. 94.

12. Aronovici, V.S.; Schneider, A.D. Deep percolation through pullman Soils Texas High plains. J. Soil Water Conserv. 1972, 27, 70-73.

13. Taylor, H.M.; van Doren, C.E.; Godfrey, C.L.; Coover, J.R. Soils of the Southwestern Great Plains Field Station; Texas Agricultural Experiment Station: College Station, TX, USA, 1963; p. 16.

14. Ouapo, C.Z.; Steward, B.A.; DeOtte, R.E., Jr. Agronomic water mass balance vs. well measurement for assessing Ogallala Aquifer depletion in the Texas panhandle. J. Am. Water Res. Assoc. 2014, 50, 483-496. [CrossRef]

15. Osterkamp, W.R.; Wood, W.W. Playa-lake basins on the Southern High plains of Texas and New Mexico: part I. Hydrologic, geomorphic, and geologic evidence for their development. Geol. Soc. Am. Bull. 1987, 99, 215-223. [CrossRef]

16. Wood, W.W.; Osterkamp, W.R. Playa-lake basins on the Southern High plains of Texas and New Mexico: part II. A hydrologic model and mass-balance arguments for their development. Geol. Soc. Am. Bull. 1987, 99, 224-230. [CrossRef]

17. Gurdak, J.J.; Roe, C.D. Recharge Rates and Chemistry Beneath Playas of the High plains Aquifer-A Literature Review and Synthesis; US Geological Survey Circular 1333; US Geological Survey: Reston, VA, USA, 1999; p. 46.

18. Gurdak, J.J.; Roe, C.D. Review: Recharge rates and chemistry beneath playas of the High plains aquifer, USA. Hydrog. J. 2010, 18, 1747-1772. [CrossRef]

19. Hovorka, S.D. Quaternary evolution of playa lakes on the southern High Plains: A case study from the Amarillo area, Texas. Bur. Econ. Geol. Rep. Invest. 1995, 236, 102.

20. Scanlon, B.R.; Goldsmith, R.S. Field study of spatial variability in unsaturated flow beneath and adjacent to playas. Water Resour. Res. 1997, 33, 2239-2252. [CrossRef]

21. Reeves, C.C., Jr.; Parry, W.T. Age and morphology of small lake basins, Southern High plains, Texas and eastern New Mexico. Texas J. Sci. 1969, 20, 349-354.

22. Zartman, R.; Villarreal, C.; Hudnall, W. Cropping management system influences on playa sediments in US southern High plains. In Proceedings of the 19th World Congress of Soil Science, Soil Solutions for a Changing World, Brisbane, Australia, 1-6 August 2010.

23. Villarreal, C.J.; Zartman, R.E.; Hudnall, W.H.; Gitz, D.; Rainwater, K.; Smith, L.M. Spatial distribution and morphology of sediments in Texas Southern High plains playa wetlands. Texas Water J. 2012, 3, 1-13.

24. Texas Water Development Board. 2012 State Water Plan. 2014. Available online: http://www.twdb.state.tx. us/waterplanning/swp/2012/index.asp (accessed on 15 September 2014).

25. National Climate Data Center. NCDC Climate Data Online. 2014. Available online: http://www7.ncdc. noaa.gov/CDO/cdo (accessed on 15 September 2014).

26. National Land Cover Data. 2014. Available online: http://www.mrlc.gov/index.php (accessed on 15 September 2014).

27. ESRI. ArcMap Version 9.3 (Build 1770); ESRI Inc.: Redland, CA, USA, 2008.

28. NRCS-USDA. Geospatial Data Gateway. 2014. Available online: http://datagateway.nrcs.usda.gov/ (accessed on 15 September 2014). 
29. Gil, S.; Jones, N.L.; Maidment, D.R. Arc Hydro Groundwater, GIS for Hydrogeology; ESRI Press: Redlands, CA, USA, 2011; p. 160.

30. The SAS User's Guide, Version 9.3; SAS Institute: Cary, NC, USA, 2010.

31. Natural Resources Conversation Service. Web Soil Survey; 2014. Available online: http:/ /websoilsurvey.nrcs. usda.gov/app/Homepage.htm (accessed on 15 September 2014).

32. Ishak, A.M.; Bray, M.; Remesan, R.; Han, D. Estimating reference evapotranspiration using numerical weather modeling. Hydrol. Processes 2010, 24, 3490-3509. [CrossRef]

33. Rainwater, K.; Jackson, A.; Ingram, W.; Lee, C.Y.; Thompson, D.; Mollhagen, T.; Ramsey, H.; Urban, L. Ield demonstration of the combined effects of absorption and evapotranspiration on septic system drain field capacity. Water Environ. Res. 2005, 77, 150-161.

34. Rodriguez-Rodriguez, M.; Benavente, J.; Cruz-San Julian, J.J.; Moral Martos, F. Estimation of ground-water exchange with semi-arid playa lakes (Antequera region, southern Spain). J. Arid. Environ. 2006, 66, 272-289. [CrossRef]

35. Castanedad, C.; Garcia-Vera, M.A. Water balance in the playa lakes of an arid environment, Monegros NE Spain. Hydrogeol. J. 2008, 16, 87-102. [CrossRef]

36. Sanderson, J.S.; Kotliar, N.B.; Steingraeber, D.A.; Browne, C. Simulated natural hydrologic regime of an intermountain playa conservation site. Wetlands 2008, 28, 363-377. [CrossRef]

37. Gowda, P.; Howell, T.; Paul, G.; Colaizzzi, P.; Marek, T.; Porter, D.; Morhead, J.; Holman, D. Bushland evapotranspiration and agricultural remote sensing system (BEARS). In Proceedings of the ASA-CSSA-SSSA Annual Meeting Abstracts, No. 209-210; ASA-CSSA-SSSA Annual Meeting Abstracts, Madison, WI, USA, 7 November 2012.

38. Jones, O.R.; Eck, H.V.; Smith, S.J.; Coleman, G.A.V.; Hauser, V.L. Runoff, soil, and nutrient losses from rangeland and dry-farmed cropland in the southern High plains. J. Soil Water Conserv. 1985, 40, 161-164.

39. Gile, L.H. A classification of Ca horizons in soils of a desert region, Dona Ana County, New Mexico. Soil Sci. Soc. Am. Proc. 1961, 25, 52-61. [CrossRef]

40. Baumhardt, R.L.; Lascano, R.J. Physical and hydraulic properties of calcic horizon. Soil Sci. 1993, 155, 368-375. [CrossRef]

41. High Plains Water District. Rules of the High Plains Underground Water Conservation District No. 1. 2014. Available online: http:/ / www.hpwd.org/rules (accessed on 12 August 2014).

42. Johnson, W.P.; Rice, M.B.; Haukos, D.A.; Thorpe, P.P. Factors influencing the occurrence of inundated playa wetlands during the winter on the Texas High Plains. Wetland 2011, 31, 1287-1296. [CrossRef]

(C) 2016 by the authors; licensee MDPI, Basel, Switzerland. This article is an open access article distributed under the terms and conditions of the Creative Commons Attribution (CC-BY) license (http:/ / creativecommons.org/licenses/by/4.0/). 